\title{
Moderating Factors in Distant Investment of Corporate Venture Capital
}

\author{
Shinhyung Kang ${ }^{1}\left[\right.$ and JungTae Hwang ${ }^{2, *}$ \\ 1 School of Business, Chungnam National University, Daejeon 34134, Korea; sh.kang@cnu.ac.kr \\ 2 Department of Business Administration, Hallym University, Chuncheon 24252, Korea \\ * Correspondence: jthwang@hallym.ac.kr
}

Received: 2 February 2019; Accepted: 5 March 2019; Published: 13 March 2019

check for updates

\begin{abstract}
The role of venture capital as mediator and gatekeeper is well acknowledged and geographical barriers for open innovation have been questioned, but venture capital firms' distant investments have been investigated only rarely. The strategic benefits accrued from corporate venture capital (CVC) investment depend on the selection of target ventures. Prior research, however, overlooked the incurred information cost for identifying a potential target. Considering that innovative ventures often reside in distant locations, this paper aims to investigate what factors alleviate the information cost for CVCs when identifying target ventures in distant locations. We expect a CVC's target selection in distant locations will be limited to the ventures under a tight appropriability regime, ventures within the same industries as a CVC's business units, and ventures with pre-existing investors that a CVC has prior ties with. The hypotheses are tested with the data on CVC investments in the U.S. between 2006 and 2013. The results empirically support the hypotheses.
\end{abstract}

Keywords: corporate venture capital; information cost; distant search; partner selection

\section{Introduction}

Corporate venture capital (CVC) refers to the capital raised by established firms to acquire minority equity stakes in privately held ventures for strategic purposes [1]. CVC is one of the means to access external sources of knowledge, and its role in fostering open innovation is well documented [2,3], enhancing the productivity of research and development (R\&D) activity [4,5]. It also helps investing firms with the identification of emerging technologies [6] and appropriate candidates for strategic alliances [7] or mergers and acquisitions (M\&A) [8].

While the degree of the strategic benefits accrued from CVC investment is tied to identifying appropriate target ventures [9-11], less attention has been given to the constraints and challenges CVCs face during this target selection. The extant research assumes that the information on a potential target venture is readily available. Yet, the information on the quality of a target venture is often tacit and localized in nature. This is not only because a venture's lack of tangible assets or historical track record can increase information costs, but also because innovative ventures tend not to reveal their technological inventions to corporate investors for fear of technology misappropriation [12,13]. Moreover, target ventures with valuable knowledge and resources for CVCs often reside in distant locations $[14,15]$ and CVCs need to invest in ventures in distant regions to secure strategic benefits [16]. Geographic distance, however, increases costs for identifying an adequate target $[17,18]$, exacerbating information asymmetry and the risk of adverse selection [19]. In this paper, we therefore aim to investigate what factors alleviate the information cost for CVCs when identifying target ventures in distant locations.

To address the research question, we performed a dyadic analysis using the data on 982 investments between 870 U.S.-based ventures and 236 CVCs between 2006 and 2013. We generated 
74,450 potential investments (those that could have been realized but were not), then estimated the probability that an investment would occur between a CVC and a venture using a logit model. The empirical analysis shows that a distant CVC investment is more likely when a venture is under a tight appropriability regime, when it operates in the same industry as the corporate investor's business units, or when the corporate investor has prior ties with other investors in a syndicate involving the venture.

Identifying suitable target ventures in distant locations is related to creating strategic benefits from CVC investment, and this study provides several practical implications for formulating an effective CVC investment strategy. First, this study suggests that in order to identify ventures with innovative technology, CVCs should primarily focus on industries with tight appropriability regimes, or industries that are highly related to their business units. If CVCs intend to invest in industry sectors that are unrelated to their business units or in ventures that are unwilling to disclose their technological inventions for fear of technology misappropriation risks, the searching costs may exceed the benefits, decreasing the overall payoff of CVC investment. Second, this study reveals that a CVC's social network with other investors plays a critical role in enhancing its deal sourcing capability in distant locations. Yet, it takes time to build a good reputation and relationships with other investors in the VC community. Consequently, top managers need to retain a long-term perspective on their CVC unit and be patient if CVC investments do not generate immediate strategic benefits.

The study makes three contributions to research in this area. First, it extends the CVC literature by investigating when a particular dyad is formed, especially between distant actors. Past research has primarily focused on the strategic benefits of CVC investment and the conditions that stimulate established firms to pursue it, paying less attention to the identification of investment opportunities. As this article focuses on distant CVC investments, the results have implications for the characteristics of ventures that bear less information cost. Next, this study examines other aspects of inefficiencies encountered by investors engaging in CVC investment. Prior research, drawing on resource dependence theory and transaction cost economics, has highlighted the risk of ex post value appropriation hazards for ventures [20,21], suggesting that CVC investment would not occur in the absence of appropriate defense mechanisms for them. In contrast, this study stresses the existence of ex ante hazards that defer corporate investors from investment. Third, this paper extends research on the effects of geographic distance on inter-firm tie formation to the CVC investment context. This study investigates the factors that alleviate information cost when identifying investment targets in distant locations.

The outline of the article is as follows. Part II includes theory and hypotheses development. Part III describes the data, the sample, and the methods used to test the hypotheses. Part IV provides the results of the empirical analysis. Part V concludes the article.

\section{Theory and Hypotheses}

\subsection{Geographic Distance and the Likelihood of CVC Investment}

Prior research considering diverse market settings has suggested that geographic distance exacerbates information asymmetry and the risk of subsequent adverse selection. Geographic distance increases the cost of collecting local information $[22,23]$ and reduces the quality of information about exchange partners [24]. This creates an information asymmetry between distant firms, exposing them to the risk of adverse selection [19]. For instance, Garmaise and Moskowitz [24] examined the commercial real estate market and found that traders resolve information asymmetries by purchasing nearby properties rather than those in distant regions. Similarly, Chakrabarti and Mitchell [14] argued that the difficulty of searching for new resources increases with distance, particularly when the search process requires gathering a considerable amount of information. More recently, Reuer and Lahiri [18] argued that geographic distance inhibits the formation of R\&D alliances by increasing the risk of adverse selection. 
Extending the above studies to the CVC investment context suggests that the likelihood of CVC investment should decrease with geographic distance. Information asymmetry is prevalent in venture capital investment because ventures largely lack tangible assets and historical track records, in addition to the uncertainty about the market potential of their inventions $[25,26]$. Moreover, information costs are higher for corporate investors than for other types of VC investors. As CVCs value strategic objectives above financial returns $[27,28]$, ventures are reluctant to reveal their inventions to CVCs for fear of technology leakage $[13,20]$. Thus, increased information costs lead to a serious risk of adverse selection, hampering the likelihood of distant CVC investment.

Hypothesis 1. The geographic distance between a corporate investor and a venture is negatively related to the likelihood of CVC investment.

\subsection{Geographic Distance and Appropriability Regimes}

The fact that costs of gathering information on exchange partners increase with geographic distance, exacerbating information asymmetry and the risk of adverse selection for prospective partners, has been tested in a wide range of market settings [29]. We add nuance to this by arguing that the likelihood of a distant CVC investment depends upon the appropriability regime of target ventures. An appropriability regime is "the environmental factors, excluding firm and market structure, that govern an innovator's ability to capture the profits generated by an innovation" [30] (p. 287). Among the legal instruments that reinforce appropriability are patents and trade secrets [31,32]. A patent provides the holder with the right to exclude others from using the same technology [33] and to prosecute those who infringe on the patent. Trade secrets protect intellectual property that cannot be patented [34], such as know-how and customer lists. It is illegal to improperly uncover or use illicitly procured trade secrets, and such actions can result in litigation.

Corporate investors are better able to obtain information on the quality of a target venture under a tight appropriability regime. First, a venture under a tight appropriability regime applies for more patents, which have signaling effects for investors. Information on intellectual property is particularly critical for assessing ventures in their early stages. For instance, Hoenen, Kolympiris, Schoenmakers, and Kalaitzandonakes [35] found that ventures with substantial patent applications attracted and received more first-round funding from venture capital firms. Second, effective legal instruments shield ventures from potential resource misappropriation by corporate investors [13,21]. Ventures can thus safely disclose their intellectual property regardless of corporate investors' strategic intentions. As patents are codified forms of knowledge, patents can reduce information costs in technology transfer. Therefore, a corporate investor's costs of gathering information and appraising the strategic value of a potential target are reduced for a target venture under a tight appropriability regime. In contrast, ventures under a weak appropriability regime are cautious about such disclosures, increasing the adverse selection risk for corporate investors [13]. As the availability of relevant information is critical in forming a distant tie [36], we posit the following.

Hypothesis 2. The tightness of a venture's appropriability regime weakens the negative relationship between the geographic distance and the likelihood of CVC investment.

\subsection{Geographic Distance and Industry Relatedness}

Industry relatedness (i.e., product market relatedness) is also an important factor in distant CVC investment. First, a corporate investor is more capable of searching for and identifying a potential target in its own and related industries. Previous studies of alliance and acquisition suggest that information costs and the risk of adverse selection when forming an inter-firm relationship reduce as the product market relatedness between exchange partners rises due to the similarity of products and technologies, which may enhance the firm's ability to efficiently and effectively identify and judge the various characteristics of its exchange partner [18,37-41]. Similarly, corporate 
investors find more opportunities for intra-industry deals due to referrals from engineers and business unit managers in their parent companies [42,43]. These potential targets are generally companies that have been considered suppliers or business partners and need assistance to grow further [44]. Second and more importantly, the executives at headquarters (who make the final decision on a deal) have better understanding of potential targets in related business domains. In contrast, it is more difficult to understand the contribution of and claims made by ventures in different industries. As misunderstandings between partners could undermine the collaborative environment [45], the negative effect of geographic distance on interactions and trust-building will be exacerbated further. Hence, we hypothesize the following.

Hypothesis 3. When a corporate investor and a venture operate in the same industry, the negative relationship between the geographic distance and the likelihood of CVC investment is weakened.

\subsection{Geographic Distance and CVC's Prior Syndication Ties with Pre-Existing Investors}

Corporate investors lack sufficient social capital in the VC community to proactively source deals. CVCs are composed of employees transferred from their business units [46]. CVCs prefer fixed salaries to performance-based pay in order to maintain pay equality and avoid employee resentment [46]. It is thus a challenge to recruit investment experts from outside the business units' boundaries. Moreover, entrepreneurs do not like CVCs taking the lead position in funding rounds, given their lack of experience in structuring deals and arranging additional financing [47]. Therefore, CVCs participate in subsequent rounds through invitations from the pre-existing investors in a venture [46].

In this vein, we additionally argue that a $C C^{\prime}$ 's prior syndication ties with the pre-existing $\mathrm{VC}$ investors in a venture are important in reducing the information costs associated with a distant CVC investment. The pre-existing investors, those that have participated in a venture's previous funding rounds, have more localized and tacit information on the venture than other investors in later rounds do. As firms build trust through repeated interactions [48,49], the quality of information transmitted from the pre-existing investors to a corporate investor depends upon the co-investment records between them. Moreover, VC investors are more likely to propose syndication to a corporate investor with which they have previously collaborated, because they anticipate fewer conflicts of interest in investment objectives $[50,51]$ and expect to create more value from the collaboration $[52,53]$. In sum, we posit the following.

Hypothesis 4. Prior syndication ties between a corporate investor and pre-existing investors in a venture weaken the negative relationship between the geographic distance and the likelihood of CVC investment.

\section{Data and Methods}

\subsection{Data and Sample}

Using the Thomson ONE database, we first collected data on CVC investment transactions in the U.S. between 2006 and 2013. We considered the following four issues in gathering the data. First, we limited corporate investors to those in COMPUSTAT Global and North America databases. Second, we excluded corporate investors that seemed irrelevant to the strategic objectives. For instance, we removed the investments from financial corporations (for example, Royal Bank of Canada and AIG Private Equity), non-profit corporations (for example, Kaiser Permanente), and pension funds (for example, GE Pension Funds). Third, the data was restricted to the ventures that had completed their first funding round after 2000, because the VC environment changed completely after the IT bubble burst in 2000. Fourth, the ventures that received CVC investment in the first round were also removed, as investors generally rely on social capital for identifying a distant target [26]. Subsequently, we identified 982 CVC investments between 236 CVCs and 870 U.S.-based ventures. 
The unit of analysis is a CVC-venture dyad. The opportunity set of potential CVC investment deals included all feasible dyads between active CVCs and ventures that were at risk of receiving the first CVC investment between 2006 and 2013. Namely, we estimated the probability that an investment would occur between a CVC $i$ and a venture $j$ using a logit model, similar to prior research on partner selection $[13,26,54,55]$. Based on the list of 236 CVCs and 870 U.S.-based ventures, we generated 75,522 potential CVC investment dyads, among which 74,540 were unrealized and 982 were realized. We constructed 74,450 potential but unrealized investment dyads (those that could have occurred but did not) by matching each CVC with the ventures that received investment from other CVCs in a particular year. We then assessed the 982 actual investments relative to the unrealized investments.

We focused on U.S.-based ventures for several reasons. First, a single-country focus allowed us to control any institutional forces that may affect the investment activity [56]. VC investment may exhibit different patterns across countries, and this could confound the distance effects. Second, the U.S. VC market is the most developed in the world, with the highest proportion of CVC investment. Moreover, global conglomerates are attracted to innovation clusters such as Silicon Valley in order to gain access to advanced technologies [57,58]; the U.S. VC market thus provides a strong empirical base with enough dispersion in geographic distance. Third, unlike other countries, U.S. VC investments are thoroughly tracked in the Thomson ONE database [59].

\subsection{Variables and Measurement}

CVC investment $i_{i j}$. The dependent variable is a dyad-level dummy variable that captures the likelihood of CVC investment between a CVC $i$ and a venture $j$. Specifically, it takes the value of 1 if the CVC investment is materialized, and 0 otherwise. Given the dichotomous nature of the dependent variable, a logit regression model was applied for the analysis. The standard errors were estimated using the cluster option provided by STATA. We clustered the residuals by ventures. As a robustness check, we also clustered the residuals by corporate investors. The results are the same with slightly different $p$-values (not shown here).

Geographic distance $i j$. To calculate the geographic distance between a CVC $i$ and a venture $j$ in each investment dyad, the zip codes of a CVC's parent firm headquarters and the main office of a venture were obtained. Location information for a venture was taken from Thomson ONE and that for a CVC's parent firm was obtained from COMPUSTAT. After identifying the zip codes, data on the associated latitude and longitude were collected from Google Maps, and the great circle distance formula, as used in previous studies [18,26], was applied. A log transformation of the geographic distance (in kilometers) was used to reduce skewness.

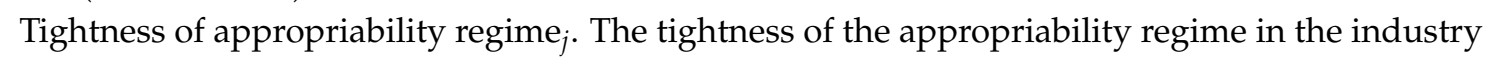
of a venture $j$ was measured using the survey data from Business R\&D and Innovation Survey (BRDIS), conducted by the U.S. Census Bureau. This survey reports the percentage of companies in each industry (using North American Industry Codes, NAIC) that reported each intellectual property protection instrument as being "very important", "somewhat important", or "not important" to them. The protection instruments surveyed included utility patents, design patents, trademarks, copyrights, trade secrets, and mask works. The percentage scores for the "very important" ranking for each protection mechanism were summed up for each industry. Since the survey was carried out from 2008 to 2010, the average of the three years' scores was used.

Industry overlap $i j$. To test Hypothesis 3 , a variable determining whether a CVC $i$ and a venture $j$ operate in the same industry was measured. The six-digit NAICs for a venture $j$ (provided by Thomson ONE) and the business units of a CVC $i$ (collected from Lexis-Nexis and COMPUSTAT) were used. The value of 1 was assigned if the NAIC of a venture $j$ matched any business units of a CVC $i$ at the six-digit NAIC level, and 0 otherwise.

CVC's prior ties with pre-existing investors ${ }_{i j}$. We first identified the pre-existing investors of a venture $j$, the investors that participated in the funding rounds prior to the focal round that the venture received during its first CVC investment. We then counted the number of ventures that a CVC $i$ had 
co-invested with each of the pre-existing investors of a venture $j$ during the previous five years (from $t-5$ till $t-1)$. We averaged these numbers for all the pre-existing investors of a venture $j$ and logged to reduce skewness.

Control Variables. Ventures mitigate the risk of resource expropriation by deferring CVC investment to later rounds [21]. Thus, the log of the round number within which a venture $j$ received CVC investment (Round number ${ }_{j t}$ ) was added. Moreover, a venture's affiliation with prominent VCs is a strong signal of its quality and acts as a social defense mechanism against CVCs [20]. As in prior studies, the eigenvector centrality [60] of each pre-existing investor was calculated using the number of ventures that each investor had co-invested with another investor in the U.S. during the previous five years (from $t-5$ till $t-1$ ). In this study, we used the average of the eigenvector centrality scores for all the pre-existing investors of a venture $j$ in the year $t$ that the venture received CVC investment (Centrality of pre-existing investors ${ }_{j t}$ ).

The degree of complementary resource need of a venture $j$ was considered, following Katila et al. [21]. Thus, we calculated the industry average ratios of fixed assets to sales (Manufacturing resource need ${ }_{j t}$ ) and advertising expenses to sales (Marketing resource need ${ }_{j t}$ ) of a venture $j$ in the year $t$ that the venture received CVC investment. The industry-level data were collected from COMPUSTAT at the three-digit NAIC level. The location of a venture $j$ was also controlled. When a venture is located in a cluster region, it is more likely that information on its performance circulates within

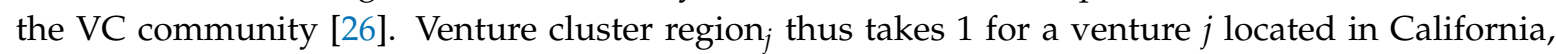
Massachusetts, or Texas, and 0 otherwise.

The characteristics of a CVC $i$ also matter. First, we measured the logged value of the revenue size of the parent firm of a CVC $i$ in the year $t\left(\right.$ Revenue size $\left._{i t}\right)$, since larger corporations are likely to have more resources to provide [61]. Second, we also controlled a CVC's preference for target industries. CVC's industry preference ${ }_{i j}$ was coded as 1 if the industry a venture $j$ matched the stated target industry of a CVC $i$, and 0 otherwise. Third, we counted the number of deals in which a CVC $i$ participated during the previous five years to control the CVC's experience. In the analysis, the logged value, after adding one, was used to reduce skewness (CVC experience ${ }_{i t}$ ).

Macro-level factors were also considered. First, a venture's receptiveness to CVC investment is affected by its economic context [62]. Therefore, following Dess and Beard [63], we constructed Industry size ${ }_{j t}$, Industry growth ${ }_{j t}$, and Industry uncertainty ${ }_{j t}$ variables for a venture $j$ in the year $t$ that the venture received CVC investment. COMPUSTAT was used to obtain the industry-level data for the focal year at the three-digit NAIC level. The log-transformed annual amount of total VC investments

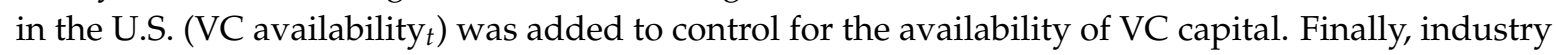
dummy variables for ventures were added to control for any industry fixed effects.

\section{Results}

\subsection{Descriptive Statistics and Correlations}

Table S1 (in Supplementary) reports descriptive statistics and a correlation matrix for the variables analyzed. The average distance in the sample was $5349 \mathrm{~km}$. The average distances of realized and unrealized CVC investment dyads were $4733 \mathrm{~km}$ and $5357 \mathrm{~km}$, respectively, and this difference was statistically significant $(t=5.078, p<0.001)$. The correlation matrix shows that most pairwise correlation coefficients for the variables were less than 0.220 , excluding those for the Industry uncertainty $_{j t}$-Tightness of appropriability regime T $_{j}(-0.418)$ and Industry size ${ }_{j t}-$ Manufacturing resource needs $s_{j t}(0.422)$ pairs. However, as the variance inflation factor (VIF) scores for all variables (not presented here) were below the cut-off value of 2.50 , there appeared to be no multicollinearity problem.

\subsection{Regression Results}

The results of the logit regression analysis are presented in Table 1. In Model 1, the Geographic distance ${ }_{i j}$ variable was presented to check the distance barrier in CVC investment. Models 2-4 each 
introduced one of three interaction terms. All five models were highly significant (all $p<0.001$ ). Wald tests on the variables in the models indicated that the addition of each interaction term substantially improved the explanatory power of the model (Geographic distance $i j(p<0.001)$, Geographic distance $i j$ $\times$ Tightness of appropriability regime $_{j}(p<0.01)$, Geographic distance $e_{i j} \times \operatorname{Industry~overlap}_{i j}(p<0.01)$, and Geographic distance $i j \times C$ CVC's prior ties with pre-existing investors $\left._{i j t}(p<0.001)\right)$.

Table 1. Logit regression of the likelihood of CVC investment.

\begin{tabular}{|c|c|c|c|c|}
\hline \multicolumn{5}{|c|}{ Dependent Variable: The likelihood of CVC Investment $_{i j}$} \\
\hline Variables & Model 1 & Model 2 & Model 3 & Model 4 \\
\hline Geographic distance $_{i j}$ & $\begin{array}{l}-0.067^{* * *} \\
(0.019)\end{array}$ & $\begin{array}{l}-0.158^{* * *} \\
(0.036)\end{array}$ & $\begin{array}{l}-0.104^{* * *} \\
(0.023)\end{array}$ & $\begin{aligned}- & 0.124^{* * *} \\
& (0.021)\end{aligned}$ \\
\hline $\begin{array}{c}\text { Geographic distance }_{i j} \times \text { Tightness of } \\
\text { appropriability regime } \\
\end{array}$ & & $\begin{array}{l}0.079 * * \\
(0.029)\end{array}$ & & \\
\hline $\begin{array}{c}\text { Geographic } \text { distance }_{i j} \times \text { Industry } \\
\text { overlap }_{i j}\end{array}$ & & & $\begin{array}{l}0.093 * * \\
(0.036)\end{array}$ & \\
\hline $\begin{array}{c}\text { Geographic distance }_{i j} \times \text { CVC's prior ties }^{\prime} \\
\text { with preexisting investors } \\
i j t\end{array}$ & & & & $\begin{array}{l}0.128^{* * * *} \\
(0.026)\end{array}$ \\
\hline Tightness of appropriability regime $e_{j}$ & $\begin{array}{l}-0.067^{*} \\
(0.034)\end{array}$ & $\begin{array}{l}-0.654^{* *} \\
(0.216)\end{array}$ & $\begin{array}{l}-0.040 \\
(0.036)\end{array}$ & $\begin{array}{l}-0.072 * \\
(0.035)\end{array}$ \\
\hline Industry overlap $i j$ & $\begin{array}{c}1.124^{* * *} \\
(0.084)\end{array}$ & $\begin{array}{c}1.166^{* * *} \\
(0.086)\end{array}$ & $\begin{array}{c}0.454 \\
(0.270)\end{array}$ & $\begin{array}{l}1.125^{* * * *} \\
(0.083)\end{array}$ \\
\hline $\begin{array}{l}\text { CVC's prior ties with preexisting } \\
\text { investors } i j t\end{array}$ & $\begin{array}{c}1.427^{* * *} \\
(0.101)\end{array}$ & $\begin{array}{l}1.420^{* * *} \\
(0.101)\end{array}$ & $\begin{array}{l}1.429 * * * \\
(0.100)\end{array}$ & $\begin{array}{l}0.584 * * \\
(0.196)\end{array}$ \\
\hline Round number $_{j t}$ & $\begin{array}{l}0.056^{*} \\
(0.028)\end{array}$ & $\begin{array}{l}0.059^{*} \\
(0.028)\end{array}$ & $\begin{array}{l}0.058^{*} \\
(0.028)\end{array}$ & $\begin{array}{l}0.066^{*} \\
(0.029)\end{array}$ \\
\hline Centrality of preexisting investors ${ }_{j t}$ & $\begin{array}{l}-7.393^{* * *} \\
(0.800)\end{array}$ & $\begin{array}{l}-7.373 * * * \\
(0.800)\end{array}$ & $\begin{array}{l}-7.443^{* * *} \\
(0.802)\end{array}$ & $\begin{array}{l}-7.752^{* * *} \\
(0.805)\end{array}$ \\
\hline Manufacturing resource need ${ }_{j t}$ & $\begin{array}{c}0.002 \\
(0.004)\end{array}$ & $\begin{array}{l}0.001 \\
(0.004)\end{array}$ & $\begin{array}{c}0.001 \\
(0.004)\end{array}$ & $\begin{array}{c}0.000 \\
(0.004)\end{array}$ \\
\hline Marketing resource need j $_{t}$ & $\begin{array}{l}-0.060 * * \\
(0.019)\end{array}$ & $\begin{array}{l}-0.062 * * \\
(0.020)\end{array}$ & $\begin{array}{l}-0.061^{* *} \\
(0.019)\end{array}$ & $\begin{array}{l}-0.060^{* *} \\
(0.020)\end{array}$ \\
\hline Venture cluster region $_{j}$ & $\begin{array}{c}0.002 \\
(0.030)\end{array}$ & $\begin{array}{c}0.014 \\
(0.030)\end{array}$ & $\begin{array}{c}0.014 \\
(0.030)\end{array}$ & $\begin{array}{c}0.030 \\
(0.030)\end{array}$ \\
\hline CVC experience $_{i t}$ & $\begin{array}{c}0.173^{* * *} \\
(0.030)\end{array}$ & $\begin{array}{c}0.173^{* * *} \\
(0.030)\end{array}$ & $\begin{array}{l}0.174^{* * *} \\
(0.030)\end{array}$ & $\begin{array}{l}0.180^{* * * *} \\
(0.030)\end{array}$ \\
\hline Revenue size $_{i t}$ & $\begin{array}{l}0.107^{* * *} \\
(0.026)\end{array}$ & $\begin{array}{l}0.107^{* * *} \\
(0.026)\end{array}$ & $\begin{array}{c}0.109 * * * \\
(0.026)\end{array}$ & $\begin{array}{l}0.112^{* * *} \\
(0.027)\end{array}$ \\
\hline CVC's industry preference $_{i j}$ & $\begin{array}{c}1.107^{* * *} \\
(0.125)\end{array}$ & $\begin{array}{c}1.082^{* * *} \\
(0.126)\end{array}$ & $\begin{array}{l}1.089^{* * *} \\
(0.125)\end{array}$ & $\begin{array}{l}1.082 * * * \\
(0.126)\end{array}$ \\
\hline Industry size ${ }_{j t}$ & $\begin{array}{c}0.034 \\
(0.024)\end{array}$ & $\begin{array}{c}0.025 \\
(0.024)\end{array}$ & $\begin{array}{c}0.024 \\
(0.024)\end{array}$ & $\begin{array}{c}0.040 \\
(0.024)\end{array}$ \\
\hline Industry uncertainty $j t$ & $\begin{array}{c}0.106 \\
(0.265)\end{array}$ & $\begin{array}{c}0.088 \\
(0.267)\end{array}$ & $\begin{array}{c}0.101 \\
(0.266)\end{array}$ & $\begin{array}{c}0.097 \\
(0.267)\end{array}$ \\
\hline Industry growth $_{j t}$ & $\begin{array}{l}-0.015^{* * *} \\
(0.003)\end{array}$ & $\begin{array}{l}-0.016^{* * *} \\
(0.003)\end{array}$ & $\begin{array}{l}-0.015^{* * *} \\
(0.003)\end{array}$ & $\begin{array}{l}-0.015^{* * *} \\
(0.003)\end{array}$ \\
\hline VC availability $t$ & $\begin{array}{c}-0.274 * \\
(0.119)\end{array}$ & $\begin{array}{c}-0.263 * \\
(0.120)\end{array}$ & $\begin{array}{c}-0.252 * \\
(0.119)\end{array}$ & $\begin{array}{c}-0.239 * \\
(0.120)\end{array}$ \\
\hline Constant & $\begin{array}{l}-3.017^{*} \\
(1.287)\end{array}$ & $\begin{array}{c}-2.483+ \\
(1.289)\end{array}$ & $\begin{array}{l}-3.040^{*} \\
(1.285)\end{array}$ & $\begin{array}{l}-3.066^{*} \\
(1.290)\end{array}$ \\
\hline $\begin{array}{l}\text { Industry dummy }_{j} \\
\text { Log Likelihood }\end{array}$ & -4673.8 & -4669.4 & -4669.6 & 4662.1 \\
\hline
\end{tabular}

Note: $\mathrm{N}=75,522$ potential CVC investment dyads; $+p<0.1,{ }^{*} p<0.05,{ }^{* *} p<0.01,{ }^{* * *} p<0.001$. 
Hypothesis 1 predicted that the likelihood of CVC investment decreases as the distance between a CVC $i$ and a venture $j$ increases. The coefficient on Geographic distance $i j$ was negative and significant in Model $2(-0.067, p<0.001)$ and in the other models (all $p<0.001)$, supported this hypothesis. Thus, corporate investors are less likely to carry out distant CVC investments, presumably due to the information asymmetry tied to geographic distance.

Hypotheses 2-4 suggested that the likelihood of CVC investment in distant locations depends upon characteristics of target ventures that affect information cost. Models 2-4 tested these hypotheses empirically. First, Model 2 indicated that the coefficient on Geographic distance $i j \times$ Tightness of appropriability regime ${ }_{j}$ was positive and significant $(0.079, p<0.01)$, supporting Hypothesis 2 . Thus, CVCs in distant locations are more likely to invest in ventures under a tight appropriability regime. Second, the coefficient on the Geographic distance $i j \times$ Industry overlap $_{i j}$ variable was positive and significant $(0.093, p<0.01)$ in Model 3, supporting Hypothesis 3. This indicates that a CVC is more likely to engage in a distant investment with a venture that occupies the same product market as the CVC's business units. Third, in Model 4, the coefficient on the interaction term Geographic distance $i j$ $\times \mathrm{CVC}^{\prime}$ s prior ties with pre-existing investors ${ }_{i j t}$ was positive and significant $(0.128, p<0.001)$, strongly supporting Hypothesis 4. Corporate investors thus seem to rely on prior syndication ties with other VCs to identify appropriate targets in distant locations.

\section{Discussion and Conclusions}

\subsection{Contributions and Implications}

This study has several contributions and implications. First, it contributes to the literature on the determinants of CVC investment. Extant research generally considers CVC investment as external $R \& D$ and mostly focuses on the positive effects of CVC investment on the innovation performance of established firms $[4,5,10]$. In other words, corporations initiate CVC programs to cope with rapid technological change and fierce market competition [64-66]. However, investment is not solely driven by the motivation of investors; it also requires identifying appropriate targets [67]. Particularly when promising targets are located in geographically distant regions, the large information asymmetry between investors and investees can increase the costs of identifying a target $[14,18]$. In this regard, this study shows that, in order to identify ventures that can enhance the technology base of the business units, CVCs should primarily focus on industry sectors with tight appropriability regimes or that are highly related to their business units. These are the industry sectors where CVCs can reduce target searching costs. This article also stresses the important role of a corporate investor's social network in the VC community. It takes time to build relationships with other investors, and consequently, top managers need to retain a long-term perspective on CVC investment activities rather than demanding immediate strategic benefits.

Furthermore, this study has identified a type of inefficiency in realizing CVC investment that has not been considered previously. It has been argued that the expected ex post hazards faced by ventures inhibit CVC investment. For instance, even if CVCs seek to invest in ventures under a weak intellectual property regime [68], the chances of such investment actually happening are low [13]. This is because entrepreneurs will turn down those investment offers unless the corporate investors provide substantial cash [69] or complementary assets that offset the risk of value appropriation [21]. In contrast, this study has emphasized the ex ante hazards from the corporate investor's perspective. However, it is not the intention of this paper to weigh the relative importance of ex post and ex ante hazards. Rather, it seeks to provide a complementary theory to guide the investigation of other inefficiencies encountered by firms when engaging in CVC investment.

At the broadest level, this study extends research on the effects of geographic distance on tie formations to an open innovation context. A considerable body of literature has discussed the impact of geographical proximity on open innovation [70-72]. This study adds to that literature, with solid empirical analysis, in the field of CVC investment. The finding that the geographic distance between 
a corporate investor and a venture decreases the probability of CVC investment is consistent with prior research on the risk of adverse selection due to distance. Geographic distance has been shown to exacerbate information asymmetry and the subsequent risk of adverse selection, reducing the likelihood of inter-firm tie formation [14,18]. Tie formation involves various costs associated with identifying an appropriate partner and evaluating its resources. Since those deciding whether to form an inter-firm tie have physical and cognitive constraints [73], searches are usually limited to nearby firms [14]. Moreover, when the evaluation involves tacit and firm-specific information, such as R\&D resources, a distant appraiser bears considerable costs for obtaining the needed information [18,22]. Similarly, corporate investors must gather firm-specific, tacit, and local information in order to assess the quality and strategic potential of a target venture. The effects of geographic distance are thus substantial in CVC investment, increasing the risk of adverse selection for corporate investors in distant locations.

\subsection{Limitations and Future Research}

This study is not without limitations. First, its empirical analysis is weak in addressing the endogeneity problem that arises from the correlation between the explanatory variables and the error term. Li [74] describes the two sources of endogeneity-reverse causality and spurious correlation-and suggests some remedies to deal with this problem. The simplest approach is including potential factors that jointly affect the dependent variable, CVC investment $i_{i j}$, and the independent variable, Geographic distance $i j$. For instance, the social network among CVC unit managers, VC fund managers, and entrepreneurs may facilitate CVC investment deals [75]. However, these factors could not be included in the empirical analysis due to the constraints of the secondary data. Among other remedies suggested by Li [74], applying fixed effect or dynamic models and using lagging dependent and independent variables were not feasible since the empirical analysis is based upon cross-sectional data. We could have adopted the instrumental variable approach but finding good instrumental variables that are only associated with the independent variable, Geographic distance ${ }_{i j}$, was tricky. We hope future research into CVC investment will deal with these endogeneity issues.

Second, the sensitivity of different measures of firm size is not considered. Firm size is an important and fundamental firm characteristic. However, there are various measures for firm size with different implications [76]. In the context of CVC investment, the parent firm size matters, as larger firms are likely to have more resources to provide and they can bear higher risks. Thus, we used the total sales of a CVC's parent firm as one way to measure firm size. In line with Dang et al. [76], we also used total assets as an alternative measure for parent firm size. The results were robust regardless of firm size proxies. Yet, the sensitivity of other measures, such as market cap and the number of employees, could not be tested due to the constraints of the data.

Third, some venture characteristics are insufficiently controlled. For example, venture size could not be included in the control variables, since financial data were not available for the ventures. The need for CVC investment and the appropriability regime of a venture were operationalized based on industry-level data. In addition, though a control variable, "Marketing resource need" (i.e., average intensity of advertising at industry level) was employed, it did not seem to improve the possibility of attracting CVC investment. Considering ventures generally lack resources for marketing, this result is unexpected. Whether this is simply due to CVCs' preference against independent venture capital firms or marketing-intensive firms being less keen to fundraise through CVC, remains to be investigated.

With regard to future research, it would be interesting to consider how ex post and ex ante hazards interact in geographically distant CVC investment. As argued in recent studies of CVC investment, ventures are reluctant to receive CVC investment unless their intellectual property is protected from potential misappropriation by corporate investors $[13,20,21]$. Thus, ex post and ex ante hazards have contrasting influences on determining who partners with whom. For instance, a venture's concerns about resource misappropriation are magnified when it operates in the same industry as a CVC's business unit, competing in the same product market [13,77]. On the other hand, this study argues 
that adverse selection concerns motivate corporate investors to seek out ventures within the same industry. Hence, depending on the relative bargaining power at the stage of materializing CVC investment, industry overlap can have contrasting effects (refer to the debate between Mason and Drakeman [78] and Diestre and Rajagopalan [79]). Consequently, future research should examine the effects of geographic distance while considering the relative bargaining power of both parties involved in the CVC investment.

\subsection{Conclusions}

CVC investment is a tool for corporations to take advantage of emerging market and technological opportunities. Strategically appropriate ventures, however, are often located in regions distant from CVC units. For instance, cutting-edge IT ventures are concentrated in Silicon Valley, whereas large corporations interested in investing in emerging IT technologies are dispersed worldwide. Such corporations can thus hardly avoid distant CVC investment. In this context, we investigated the influence of geographic distance on the target selection of corporate investors and what factors moderate this influence. The main finding is that a distant CVC is more likely to invest in ventures with potentially lower information cost, such as those under a tight appropriability regime, those within the same industries as a CVC's business units, and those backed by the investors that a CVC has prior syndication ties with. Consequently, in order to geographically expand its investment portfolio, a CVC needs to build relationships with other VCs.

Supplementary Materials: The following are available online at http:/ /www.mdpi.com/2199-8531/5/1/19/s1, Table S1: Correlation matrix of variables with descriptive statistics.

Author Contributions: Conceptualization, S.K. and J.T.H.; data curation and formal analysis, S.K.; Writing — Original Draft preparation, S.K.; Writing-Review and Editing, S.K. and J.T.H.

Conflicts of Interest: The authors declare no conflict of interest.

\section{References}

1. Gompers, P.; Lerner, J. The Determinants of Corporate Venture Capital Success: Organizational Structure, Incentives and Complementarities; NBER Working Paper Series; National Bureau of Economics Research: Cambridge, MA, USA, 1998.

2. Chesbrough, H.W. Making sense of corporate venture capital. Harv. Bus. Rev. 2002, 80, 90-99.

3. Chesbrough, H.W. Open Innovation; Harvard University Press: Cambridge, MA, USA, 2003.

4. Dushnitsky, G.; Lenox, M.J. When do incumbents learn from entrepreneurial ventures? Corporate venture capital and investing firm innovation rates. Res. Policy 2005, 34, 615-639. [CrossRef]

5. Wadhwa, A.; Kotha, S. Knowledge creation through external venturing: Evidence from the telecommunications equipment manufacturing industry. Acad. Manag. J. 2006, 49, 819-835. [CrossRef]

6. Maula, M.V.; Keil, T.; Zahra, S.A. Top management's attention to discontinuous technological change: Corporate venture capital as an alert mechanism. Organ. Sci. 2013, 24, 926-947. [CrossRef]

7. Van de Vrande, V.; Vanhaverbeke, W. How prior corporate venture capital investments shape technological alliances: A real options approach. Entrep. Theory Pract. 2013, 37, 1019-1043. [CrossRef]

8. Benson, D.; Ziedonis, R.H. Corporate venture capital as a window on new technologies: Implications for the performance of corporate investors when acquiring startups. Organ. Sci. 2009, 20, 329-351. [CrossRef]

9. Keil, T.; Maula, M.; Schildt, H.; Zahra, S.A. The effect of governance modes and relatedness of external business development activities on innovative performance. Strateg. Manag. J. 2008, 29, 895-907. [CrossRef]

10. Wadhwa, A.; Phelps, C.; Kotha, S. Corporate venture capital portfolios and firm innovation. J. Bus. Ventur. 2016, 31, 95-112. [CrossRef]

11. Yang, Y.; Narayanan, V.K.; De Carolis, D.M. The relationship between portfolio diversification and firm value: The evidence from corporate venture capital activity. Strateg. Manag. J. 2014, 35, 1993-2011. [CrossRef]

12. Chesbrough, H.; Lane, D. Intel Capital: The Berkeley Networks Investment; Harvard Business Publishing: Boston, MA, USA, 2000. 
13. Dushnitsky, G.; Shaver, J.M. Limitations to interorganizational knowledge acquisition: The paradox of corporate venture capital. Strateg. Manag. J. 2009, 30, 1045-1064. [CrossRef]

14. Chakrabarti, A.; Mitchell, W. The persistent effect of geographic distance in acquisition target selection. Organ. Sci. 2013, 24, 1805-1826. [CrossRef]

15. Hsu, C.-W.; Lien, Y.-C.; Chen, H. R\&D internationalization and innovation performance. Int. Bus. Rev. 2015, 24, 187-195.

16. Zahra, S.A.; Hayton, J.C. The effect of international venturing on firm performance: The moderating influence of absorptive capacity. J. Bus. Ventur. 2008, 23, 195-220. [CrossRef]

17. Ragozzino, R.; Reuer, J.J. Geographic distance and corporate acquisitions: Signals from IPO firms. Strateg. Manag. J. 2011, 32, 876-894. [CrossRef]

18. Reuer, J.J.; Lahiri, N. Searching for alliance partners: Effects of geographic distance on the formation of R\&D collaborations. Organ. Sci. 2014, 25, 283-298.

19. Akerlof, G.A. The market for lemons: Quality uncertainty and the market mechanism. Q. J. Econ. 1970, 84, 488-500. [CrossRef]

20. Hallen, B.L.; Katila, R.; Rosenberger, J.D. How Do Social Defenses Work? A Resource-Dependence Lens on Technology Ventures, Venture Capital Investors, and Corporate Relationships. Acad. Manag. J. 2014, 57, 1078-1101. [CrossRef]

21. Katila, R.; Rosenberger, J.D.; Eisenhardt, K.M. Swimming with sharks: Technology ventures, defense mechanisms and corporate relationships. Adm. Sci. Q. 2008, 53, 295-332. [CrossRef]

22. Bell, R.G.; Filatotchev, I.; Rasheed, A.A. The liability of foreignness in capital markets: Sources and remedies. J. Int. Bus. Stud. 2012, 43, 107-122. [CrossRef]

23. Zaheer, S. Overcoming the liability of foreignness. Acad. Manag. J. 1995, 38, 341-363.

24. Bae, K.-H.; Stulz, R.M.; Tan, H. Do local analysts know more? A cross-country study of the performance of local analysts and foreign analysts. J. Financ. Econ. 2008, 88, 581-606. [CrossRef]

25. Gompers, P.A. Optimal investment, monitoring, and the staging of venture capital. J. Financ. 1995, 50, 1461-1489. [CrossRef]

26. Sorenson, O.; Stuart, T.E. Syndication networks and the spatial distribution of venture capital investments. Am. J. Sociol. 2001, 106, 1546-1588. [CrossRef]

27. Pahnke, E.C.; Katila, R.; Eisenhardt, K.M. Who Takes You to the Dance? How Partners' Institutional Logics Influence Innovation in Young Firms. Adm. Sci. Q. 2015, 60, 596-633. [CrossRef]

28. Park, H.D.; Steensma, H.K. The Selection and Nurturing Effects of Corporate Investors on New Venture Innovativeness. Strateg. Entrep. J. 2013, 7, 311-330. [CrossRef]

29. Coff, R.W. How buyers cope with uncertainty when acquiring firms in knowledge-intensive industries: Caveat emptor. Organ. Sci. 1999, 10, 144-161. [CrossRef]

30. Teece, D. Profiting from technological innovation: Implications for integration, collaboration, licensing and public policy. Res. Policy 1986, 15, 285-305. [CrossRef]

31. Anton, J.J.; Yao, D.A. Little patents and big secrets: Managing intellectual property. RAND J. Econ. 2004, 35 , 1-22. [CrossRef]

32. Katila, R.; Mang, P.Y. Exploiting technological opportunities: The timing of collaborations. Res. Policy 2003, 32, 317-332. [CrossRef]

33. Walker, R.D. Patents as Scientific and Technical Literature; Scarecrow Press: Metuchen, NJ, USA, 1995.

34. Epstein, R.A. The constitutional protection of trade secrets under the takings clause. Univ. Chic. Law Rev. 2004, 71, 57-73.

35. Hoenen, S.; Kolympiris, C.; Schoenmakers, W.; Kalaitzandonakes, N. The diminishing signaling value of patents between early rounds of venture capital financing. Res. Policy 2014, 43, 956-989. [CrossRef]

36. Garmaise, M.J.; Moskowitz, T.J. Confronting information asymmetries: Evidence from real estate markets. Rev. Financ. Stud. 2004, 17, 405-437. [CrossRef]

37. Balakrishnan, S.; Koza, M.P. Information asymmetry, adverse selection and joint-ventures: Theory and evidence. J. Econ. Behav. Organ. 1993, 20, 99-117. [CrossRef]

38. Datar, S.; Frankel, R.; Wolfson, M. Earnouts: The effects of adverse selection and agency costs on acquisition techniques. J. Law Econ. Organ. 2001, 17, 201-238. [CrossRef]

39. Hennart, J.F.; Reddy, S. The choice between mergers/acquisitions and joint ventures: The case of Japanese investors in the United States. Strateg. Manag. J. 1997, 18, 1-12. [CrossRef] 
40. Vanhaverbeke, W.; Duysters, G.; Noorderhaven, N. External technology sourcing through alliances or acquisitions: An analysis of the application-specific integrated circuits industry. Organ. Sci. 2002, 13, 714-733. [CrossRef]

41. Villalonga, B.; McGahan, A.M. The choice among acquisitions, alliances, and divestitures. Strateg. Manag. J. 2002, 26, 1183-1208. [CrossRef]

42. Leamon, A.; Hardymon, G. Intel ${ }^{\circledR} 64$ Fund; Harvard Business Publishing: Boston, MA, USA, 2000.

43. Siegel, R.; Siegel, E.; Mamillan, I.C. Corporate venture capitalists: Autonomy, obstacles, and performance. J. Bus. Ventur. 1988, 3, 233-247. [CrossRef]

44. McNally, K. Corporate Venture Capital: Bridging the Equity Gap in the Small Business Sector; Routledge: New York, NY, USA, 1997.

45. Xia, J. Mutual dependence, partner substitutability, and repeated partnership: The survival of cross-border alliances. Strateg. Manag. J. 2011, 32, 229-253. [CrossRef]

46. Dushnitsky, G.; Shapira, Z. Entrepreneurial finance meets organizational reality: Comparing investment practices and performance of corporate and independent venture capitalists. Strateg. Manag. J. 2010, 31, 990-1017. [CrossRef]

47. Maula, M.; Autio, E.; Murray, G. Corporate venture capitalists and independent venture capitalists: What do they know, who do they know and should entrepreneurs care? Ventur. Cap. 2005, 7, 3-21. [CrossRef]

48. Gulati, R. Does familiarity breed trust? The implications of repeated ties for contractual choice in alliances. Acad. Manag. J. 1995, 38, 85-112.

49. Uzzi, B. Social structure and competition in interfirm networks: The paradox of embeddedness. Adm. Sci. Q. 1997, 42, 35-67. [CrossRef]

50. Meuleman, M.; Lockett, A.; Manigart, S.; Wright, M. Partner selection decisions in interfirm collaborations: The paradox of relational embeddedness. J. Manag. Stud. 2010, 47, 995-1019. [CrossRef]

51. Mote, J. Syndication, networks and the growth of venture capital in Philadelphia, 1980-1999. Ind. Innov. 2011, 18, 131-150. [CrossRef]

52. De Clercq, D.; Dimov, D. Internal knowledge development and external knowledge access in venture capital investment performance. J. Manag. Stud. 2008, 45, 585-612. [CrossRef]

53. Huggins, R.; Johnston, A.; Thompson, P. Network capital, social capital and knowledge flow: How the nature of inter-organizational networks Impacts on innovation. Ind. Innov. 2012, 19, 203-232. [CrossRef]

54. Diestre, L.; Rajagopalan, N. Are all 'sharks' dangerous? new biotechnology ventures and partner selection in R\&D alliances. Strateg. Manag. J. 2012, 33, 1115-1134.

55. Gulati, R. Network location and learning: The influence of network resources and firm capabilities on alliance formation. Strateg. Manag. J. 1999, 20, 397-420. [CrossRef]

56. Da Gbadji, L.A.G.; Gailly, B.; Schwienbacher, A. International analysis of venture capital programs of large corporations and financial institutions. Entrep. Theory Prac. 2014, 39, 1213-1245. [CrossRef]

57. Chesbrough, H.; Tachau, J. Innovating an Outsourced RED Process for Matsushita Electric (MEI): Launching the Panasonic Digital Concepts Center; Harvard Business Publishing: Boston, MA, USA, 2002.

58. Hasegawa, K. Evolution of the corporate venture capital operations of Japanese electronics companies. In Proceedings of the First International Technology Management Conference, San Jose, CA, USA, 27-30 June 2011.

59. Maats, F.; Metrick, A.; Yasuda, A.; Hinkes, B.; Vershovski, S. On the Consistency and Reliability of Venture Capital Databases; University of California at Davis: Davis, CA, USA, 2011.

60. Bonacich, P. Factoring and weighting approaches to status scores and clique identification. J. Math. Sociol. 1972, 2, 113-120. [CrossRef]

61. Keil, T.; Maula, M.V.; Wilson, C. Unique resources of corporate venture capitalists as a key to entry into rigid venture capital syndication networks. Entrep. Theory Prac. 2010, 34, 83-103. [CrossRef]

62. Park, H.D.; Steensma, H.K. When does corporate venture capital add value for new ventures? Strateg. Manag. J. 2012, 33, 1-22. [CrossRef]

63. Dess, G.G.; Beard, D.W. Dimensions of organizational task environments. Adm. Sci. Q. 1984, $29,52-73$. [CrossRef]

64. Basu, S.; Phelps, C.; Kotha, S. Towards understanding who makes corporate venture capital investments and why. J. Bus. Ventur. 2011, 26, 153-171. [CrossRef] 
65. Sahaym, A.; Steensma, H.K.; Barden, J.Q. The influence of R\&D investment on the use of corporate venture capital: An industry-level analysis. J. Bus. Ventur. 2010, 25, 376-388.

66. Van de Vrande, V.; Vanhaverbeke, W.; Duysters, G. External technology sourcing: The effect of uncertainty on governance mode choice. J. Bus. Ventur. 2009, 24, 62-80. [CrossRef]

67. Dimov, D.; Milanov, $\mathrm{H}$. The interplay of need and opportunity in venture capital investment syndication. J. Bus. Ventur. 2010, 25, 331-348. [CrossRef]

68. Dushnitsky, G.; Lenox, M.J. When do firms undertake R\&D by investing in new ventures? Strateg. Manag. J. 2005, 26, 947-965.

69. Hellmann, T. A theory of strategic venture investing. J. Financ. Econ. 2002, 64, 285-314. [CrossRef]

70. Cooke, P. Regional knowledge capabilities and open innovation: Regional innovation systems and clusters in the asymmetric knowledge economy. In Clusters, Networks $\mathcal{E}$ Innovation; Breschi, S., Malerba, F., Eds.; Oxford University Press Inc.: New York, NY, USA, 2005; pp. 80-112.

71. Huang, F.; Rice, J. Does open innovation work better in regional clusters? Australas. J. Reg. Stud. 2013, 19, 85-120.

72. Kapetaniou, C.; Lee, S.H. Geographical proximity and open innovation of SMEs in Cyprus. Small Bus. Econ. 2019, 52, 261-276. [CrossRef]

73. Cyert, R.M.; March, J.G. A Behavioral Theory of the Firm; Prentice-Hall: Englewood Cliffs, NJ, USA, 1963.

74. Li, F. Endogeneity in CEO power: A survey and experiment. Investig. Anal. J. 2016, 45, 149-162. [CrossRef]

75. Kim, J.Y.R.; Steensma, H.K. Employee mobility, spin-outs, and knowledge spill-in: How incumbent firms can learn from new ventures. Strateg. Manag. J. 2016, 48, 1626-1645. [CrossRef]

76. Dang, C.; Li, Z.; Yang, C. Measuring firm size in empirical corporate finance. J. Bank. Financ. 2018, 86, 159-176. [CrossRef]

77. Oxley, J.E.; Sampson, R.C. The scope and governance of international R\&D alliances. Strateg. Manag. J. 2004, 25, 723.

78. Mason, R.; Drakeman, D.L. Comment on "Fishing for sharks: Partner selection in biopharmaceutical R\&D alliances" by Diestre and Rajagopalan. Strateg. Manag. J. 2014, 35, 1564-1565.

79. Diestre, L.; Rajagopalan, N. Response to Mason and Drakeman's commentary on fishing for sharks: Partner selection in biopharmaceutical R\&D alliances. Strateg. Manag. J. 2014, 35, 1566-1568.

(C) 2019 by the authors. Licensee MDPI, Basel, Switzerland. This article is an open access article distributed under the terms and conditions of the Creative Commons Attribution (CC BY) license (http:/ / creativecommons.org/licenses/by/4.0/). 